\title{
Buffered vs. Non-Buffered Aliphatic Fatty Acids and their Anti-Proliferative Effects in Human Tumor Cell Lines
}

\section{Jeff Golini ${ }^{1}$ and Wendy Jones ${ }^{2 *}$}

${ }^{1}$ All American Pharmaceutical and Natural Foods Corporation Billings, Montana, USA

${ }^{2}$ Royal Knight Incorporated, Rochester, Minnesota, USA

\begin{abstract}
Background: Tumor cells generate a micro-acidic environment due to increased fermentative metabolism and poor perfusion. It is believed that this action is responsible for creating a lower $\mathrm{pH}$ environment which promotes invasive tumor growth in primary and metastatic cancers, through a form of acid-induced micro-environmental remodeling. Dietary fats, both saturated and unsaturated, have profound impacts on the viability and growth of neoplastic cells. This study examines the impact that saturated and unsaturated fatty acids, both alkalized and nonalkalized, have on the viability and growth of various neoplastic cell lines.
\end{abstract}

Methods: In this study, the potential anti-viability and antiproliferative effects of both saturated, and an unsaturated, fatty acids, when introduced as buffered $\left(\mathrm{NaHCO}_{3}\right)$, and non buffered formulations, were investigated in a comparative fashion in a panel of tumor cell lines.

Results: We show that both buffered and non-buffered fatty acids, exerted inhibition of their proliferative activity and had a negative impact on cell viability in a concentration-dependent manner. Buffered fatty acids had a greater negative impact on all tumor cell lines.

Conclusions: Findings indicate that the environment, as well as the type of fatty acid to which the neoplastic cell line was exposed, were both important predictors of antiproliferative effects.

Keywords: Saturated vs. unsaturated fatty acids, Omega-5, Alkaline buffered fatty acids

Abbreviations: SA: Stearinic Acid; MA: Myristic Acid; PA: Palmitinic Acids; CM: Cetyl-Myristoleate

\section{Introduction}

It is believed that tumor cells, due to their altered metabolism, generate their own 'vehicle for metastasis' in the form of an acid $\mathrm{pH}$ micro-environment [1,2]. This study examines the impact that saturated and unsaturated fatty acids, both alkalized and non-alkalized, have on the viability and behavior of various neoplastic cell lines.

\section{Background}

Dietary fats, saturated and unsaturated, have profound and varied influences on the cell membrane. Studies have shown that in both whole organisms, as well as in cell cultures, saturated and unsaturated fats have the ability to impact a number of tissue and cellular metabolic functions [2-6]. The suggested mechanisms, by which these processes may be occurring, are thought to involve changes in cell membrane fluidity, and cell membrane receptor availability [7-10], as well as suppression, or up-regulation of cell-to-cell growth factor signaling $[1,11,12]$, and inflammatory factor generation $[13,14]$. Saturated vs. unsaturated lipid mediated cellular behavioral changes have been shown to impact the overall behavior [15] and the fluidity of peripheral muscle tissue. A direct relationship exists between an increase in polyunsaturated fatty acids and membrane fluidity, and the opposite (rigidity) in the presence of some monosaturated and predominantly saturated fatty acids, and cholesterol [10]. Membrane fluidity is believed to influence the capability of some cancer cells to metastasize [16].

Certain long chain, saturated and unsaturated, fatty acids alike have a demonstrated ability to inhibit abnormal cell proliferation. Stearic acid (its esters - stearates) a saturated 18 carbon chain fatty acid (octadecanoic acid), and palmitic acid (its esters - palmitates) are two fats in the saturated fatty acid family known to inhibit breast cancer cell proliferation to varying degrees. Studies suggest that the mechanism of inhibition in this case involves suppression of a cellto-cell membrane receptor epidermal growth factor signal [17] or an, as yet unidentified, cell membrane receptor signaling mechanism [18]. Certain monosaturated (MA) and polyunsaturated fatty acids (PUFAs) have also demonstrated an in vitro selective cytotoxic, or antiproliferative, effect on tumor cells, and minimal or no effect on normal cell lines $[19,20]$. Several of these novel fatty acids, possessing antiproliferative activity, have been identified belonging to the omega- 5 and omega- 9 oxygenation class. Fatty acids from these groups can act on leukocytes, platelets and endothelial cells, as well as participate in cell-cell interactions that impact micro-inflammation [20,21]. Longchain fatty acids have anti-inflammatory and anti-proliferative activity $[22,23]$. Individuals with colorectal or breast cancer have been observed having lower levels of these fatty acids [24], where as elevated levels appear to be protective [24-27].

Cetylated fatty acids are a group of naturally occurring fats which include cetyl myristoleate, cetyl myristate, cetyl palmitoleate, cetyl laureate, cetyl palmitate, and cetyl oleate. The monounsaturated, 14 carbon cis-mono form of this acid of the omega- 5 series, myristoleic

*Corresponding author: Wendy Jones, Royal Knight Incorporated, 1204 Harbor Drive SE, Ste. 100, Rochester, MN 55904, USA, Tel: 507-289-8192; E-mail:WLJ_1998@yahoo.com

Received October 20, 2014; Accepted December 18, 2014; Published December 20,2014

Citation: Golini J, Jones W (2014) Buffered vs. Non-Buffered Aliphatic Fatty Acids and their Anti-Proliferative Effects in Human Tumor Cell Lines. Single Cell Biol 4 107. doi:10.4172/2168-9431.1000107

Copyright: ( 2014 Golini J, et al. This is an open-access article distributed under the terms of the Creative Commons Attribution License, which permits unrestricted use, distribution, and reproduction in any medium, provided the original author and source are credited. 
acid has demonstrated its ability to inhibit the growth of certain oral bacteria [28], reduce cell susceptibility to infection from herpes simplex virus [29], and also possess anticancer activity, inducing apoptosis (cell death) in prostatic tumors, in vitro [30].

Another factor which is thought to influence the neoplastic cell's invasiveness is $\mathrm{pH}$. Extracellular $\mathrm{pH}$ around neoplastic cells is typically lower than that found in normal tissue, not atypically observed to be below $\mathrm{pH} 6.5$ as a consequence of lactate accumulation [31]. The $\mathrm{pH}$ of solid tumors is acidic due to increased fermentative metabolism and poor perfusion [32]. It is believed that this lower $\mathrm{pH}$ environment promotes invasive tumor growth in primary and metastatic cancers through a form of acid-induced micro-environmental remodeling [3234]. A low $\mathrm{pH}$, for instance, was shown to increase the release of active cathepsin $\mathrm{B}$, an important matrix remodeling protease in a mouse tumor model $[34,35]$. When the $\mathrm{pH}$ environment is increased through the use of sodium bicarbonate $\left(\mathrm{NaHCO}_{3}\right)$, a significant reduction in tumor growth and invasiveness has been observed in some tumor models [33], justifying the potential use of this benign alkalizing agent $\left(\mathrm{NaHCO}_{3}\right)$ in cancer therapy.

In this study, the potential antiproliferative effects of both saturated and unsaturated fatty acids, when introduced as buffered $\left(\mathrm{NaHCO}_{3}\right)$, and non buffered formulations, was investigated in a comparative fashion in a panel of tumor cell lines.

\section{Methods}

Aliphatic fatty acids (stearinic, myristic, palmitinic, and cetyl myristoleate) were tested for antiproliferative effects against human tumor cell lines. The panel included: the MGH-U1 human bladder carcinoma line, acute promyelocyte leukemia HL-60, the chronic myeloid leukemia LAMA-84, the Hodgkin-lymphoma HD-MY-Z and the multiple myeloma-derived cell lines OPM-2, U-266 and RPMI-23366. All cells where obtained from the German Collection of Microorganisms and Cell Cultures (Brounschweig, Germany) and were routinely maintained under standard conditions - RPMI-1640 medium, supplemented with $10 \%$ fetal calf serum and L-glutamine, in a $5 \% \mathrm{CO}_{2}$ humidified atmosphere (at $37 \mathrm{C}$ ).

For the cytotoxicity assessment phase, exponentially growing cells were plated in 96-well flat-bottomed microplates and allowed to grow undisturbed for 24 hours after which time they were treated with the test fats.

\section{Test Materials and Controls}

All tested compounds were dissolved in Dimethyl sulfoxide (DMSO) and deionized water (the solvent). The $\mathrm{pH}$ of the buffered fatty acids, before they were utilized, was $\mathrm{pH} 10$. This was achieved using sodium carbonate $\left(\mathrm{Na}_{2} \mathrm{CO}_{3}\right)$. A pH of 10 was selected for this experiment because, in our lab, it was observed to function the best in all our stabilized cell line studies. In addition, previous studies in our lab have indicated that in a proprietary product intended for human use, this buffering material has been shown to be ingested by humans without causing gastro intestinal problems.

After dissolution, the $\mathrm{pH}$ was adjusted back to neutrality with an organic acid before the mixture was serially diluted in RPMI-1640 to the desired level. For each concentration, 8 wells were used. A solvent only series was included as one of the controls; a cultural media only was included as the other. Cells were exposed to the test compounds, or controls, for 72 hours. After 72 hours exposure the cellular viability was monitored by the standard MTT-dye reduction assay. The relative potencies of the non-buffered and buffered fatty acids were analyzed on the basis of the $\mathrm{IC}_{50}$ values obtained. $\mathrm{IC}_{50}$ calculations were performed as follows:

\section{Linear Regression}

The simplest estimate of an $\mathrm{IC}_{50}$ is to plot $\mathrm{x}-\mathrm{y}$ and fit the data with a straight line (linear regression). An $\mathrm{IC}_{50}$ value is then estimated using the fitted line.

Linear Regression Calculation In addition, an Excel add-in was used (Figure 1).

$$
\begin{aligned}
& \mathrm{Y}=\mathrm{a}^{*} \mathrm{X}+\mathrm{b} \\
& \mathrm{IC}_{50}=(0.5-\mathrm{b}) / \mathrm{a}
\end{aligned}
$$

\section{Excel add-in}

ED50V10 (Read me) is an Excel add-in for calculating $\mathrm{IC}_{50} / \mathrm{EC}_{50}$ values. Input your data in the left columns, and your results will be shown in the right half of the Excel table.

To calculate $\mathrm{IC}_{50}$, input 50 in the "INTERPOLATE..." table (highlighted in blue), the result will be shown on the right (highlighted in green). For log-transformation, go to Data Transformation on the upper-right, input 3 in the DOSE (X-axis)/1st cell.

\section{Four-Parameter Logistic Function}

Four-parameter (A, B, C, D) logistic function (or Sigmoidal) is frequently used to fit dose-response curves. The drug data $\mathrm{x}$ is in logarithmic form. This is a standard function in most statistics software. The parameter $\mathrm{C}$ is the estimate of $\mathrm{IC}_{50}$ or $\mathrm{EC}_{50}$.

Sigmoidal Calculation (Figure 2).

$$
Y=D+\frac{A-D}{1+10(x-\log C) B}
$$

The 72 hours exposure period to both buffered and nonbuffered fats was sufficient to exert a measureable inhibitory effect on their proliferative activity. A negative impact on cell viability, in a concentration-dependent manner, was also observed across the spectrum of malignant cell lines. This allowed the calculation of the corresponding $\mathrm{IC}_{50}$ values, i.e., concentration causing half-maximal inhibition of cell viability, indicating the merit of the antiproliferative potency of the tested compounds. In Tables 1 and 2, and Figures 1-12 (data presented using standard deviation [SD]), dose-response plots show the observed shift in the $\mathrm{IC}_{50}$ values when cells were exposed to the test fats. Exposure to buffered fatty acids produced an increasingly negative growth/viability effect on each tumor cell line as the concentration of the test substance increased.

Antiproliferative Effects Observed In Tumor Cell Lines: Assessed by the MTT-dye reduction assay. Assessment performed after 72 hours continuous exposure to test substance. Each data point represents the arithmetic mean \pm SD of 8 separate experiments (Figures 1-12).

\section{Discussion}

Intracellular $\mathrm{pH}$ homeostasis is important for normal cell function. Shifts in $\mathrm{pH}$, away from neutrality, or slight alkalinity, have a profound impact on cell and organ function. Tumor cell growth and differentiation appears to favor an acetic environment. A number of studies have demonstrated that $\mathrm{pH}$ homeostasis is often shifted radically away from near neutrality toward an acetified environment 


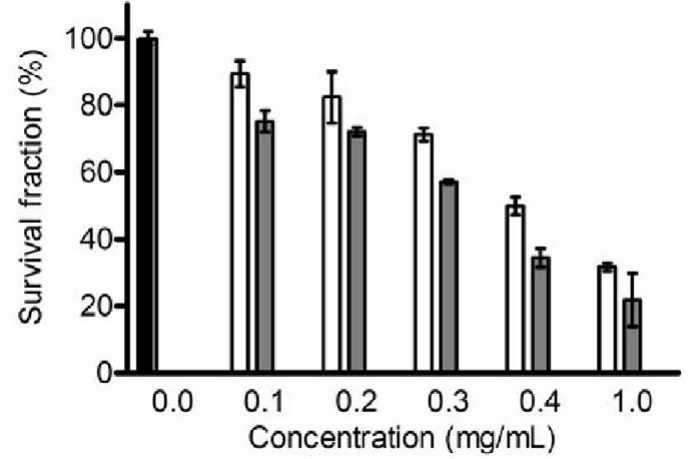

Figure 1: Non-buffered cetyl-myristoleate (white columns) Vs. buffered (grey columns) against the human acute promyelocyte leukemia HL-60

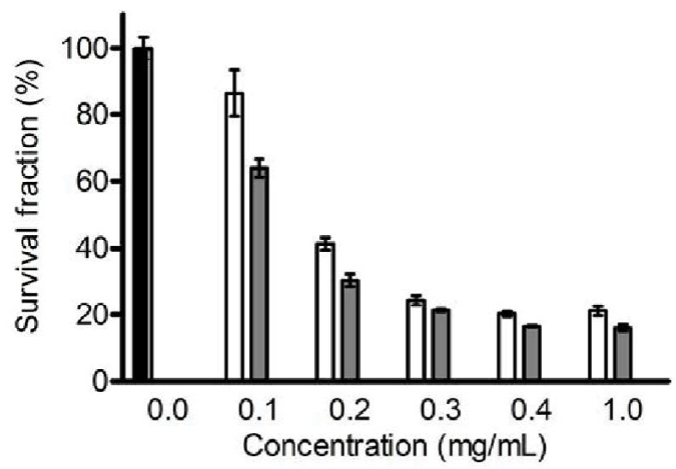

Figure 2: Non-buffered cetyl-myristoleate (white columns) Vs. buffered (grey columns) against the human chronic myeloid leukemia LAMA-84.

\begin{tabular}{|c|c|c|c|c|c|c|}
\hline Cell line & \multicolumn{5}{|c|}{$\mathrm{IC}_{50}$ (mol/L) } \\
\hline & SA & SA & MA & MA & PA & PA \\
\hline & & (buffered) & & (buffered) & & (buffered) \\
\hline & & & &
\end{tabular}

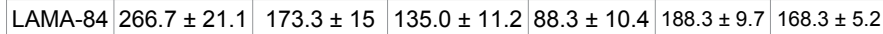

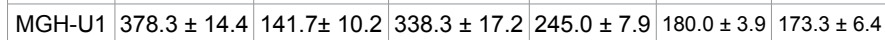

(SA) stearinic acid, (MA) myristic acid, (PA) palmitinic acid

Table 1: Antiproliferative effects of non-buffered vs. buffered, saturated fatty acids against LAMA-84 and MGH-U1 human tumor cell lines, as assessed by the MTTdye reduction assay after 72 hours continuous exposure.

\begin{tabular}{|l|l|c|c|}
\hline Cell line & Origin & \multicolumn{2}{|c|}{$\mathrm{IC}_{50}(\mathrm{mg} / \mathrm{ml})$} \\
\hline & & Non-buffered CM & Buffered CM \\
\hline HL-60 & Acute promyelocyte leukemia & $0.41 \pm 0.07$ & $0.32 \pm 0.03$ \\
\hline LAMA-84 & Chronic myeloid leukemia & $0.18 \pm 0.04$ & $0.12 \pm 0.02$ \\
\hline HD-MY-Z & Hodgkin lymphoma & $0.27 \pm 0.04$ & $0.22 \pm 0.03$ \\
\hline OPM-2 & Multiple myeloma & $0.12 \pm 0.02$ & $0.08 \pm 0.01$ \\
\hline U-266 & Multiple myeloma & $0.32 \pm 0.05$ & $0.24 \pm 0.06$ \\
\hline RPMI & Multiple myeloma & $0.20 \pm 0.03$ & $0.17 \pm 0.01$ \\
\hline
\end{tabular}

Table 2: Antiproliferative effect of buffered vs. non-buffered, cetyl-myristoleate (CM) in human tumor cell lines

in cancer [36]. This desire to generate and remain in a lower $\mathrm{pH}$ environment is likely due to certain critical transcriptional regulatory factors and signal transduction pathways, each requiring a $\mathrm{pH}$ below 6.5 to function efficiently $[37,38]$. Conversely, raising the $\mathrm{pH}$ of the immediate surroundings is expected to have a negative impact by down regulating specific tumor-related critical proteins and regulatory factors. Manipulating the $\mathrm{pH}$ of a tumor's environment in vitro, through the use of proton inhibitors or alkalizing agents has been demonstrated to be anti-neoplastic in nature, in certain cancer cell lines. In a rodent model, the oral administration of sodium bicarbonate was shown to negatively impact neoplastic metastasis by inhibiting or partially blocking angiogenesis. This rendered the cancer more susceptible to certain cytotoxic compounds [33].

Fats, especially those of the omega family, have demonstrated the ability to exert negative influences on tumor cell growth. Because these neoplastic cells exhibit significantly altered metabolic functions (and reduced $\mathrm{pH}$ generated environments), reactive oxygen species production also increases. To compensate, it has been suggested

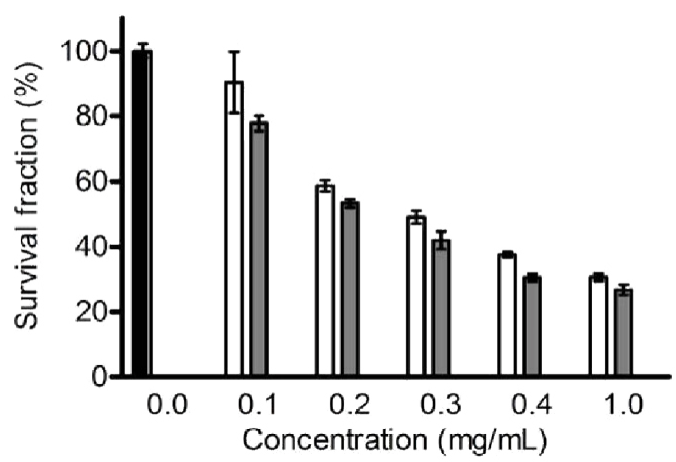

Figure 3: Non-buffered cetyl-myristoleate (white columns) Vs. buffered (grey columns) against the human Hodgkin-lymphoma HD-MY-Z.

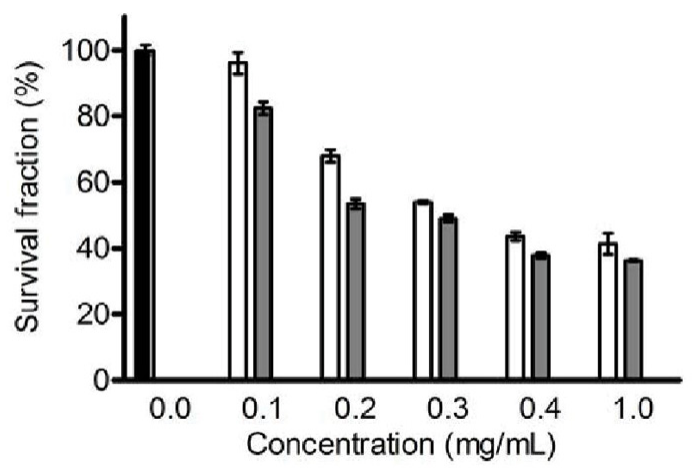

Figure 4: Non-buffered cetyl-myristoleate (white columns) vs. buffered (grey columns) against the human multiple myeloma OPM-2.

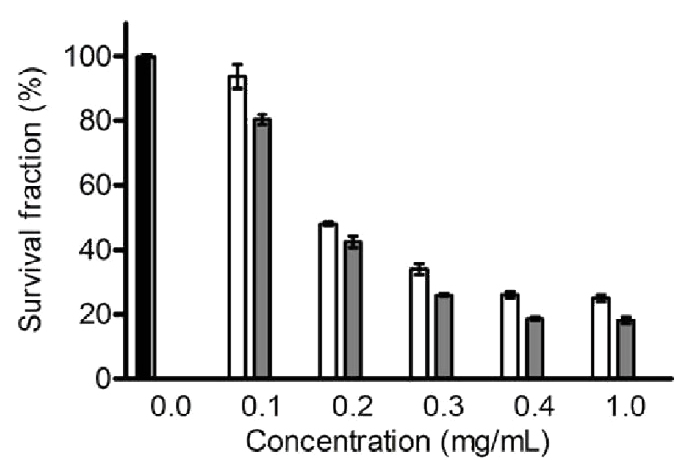

Figure 5: Non-buffered cetyl-myristoleate (white columns) vs. buffered (grey columns) against the human multiple myeloma U-266. 


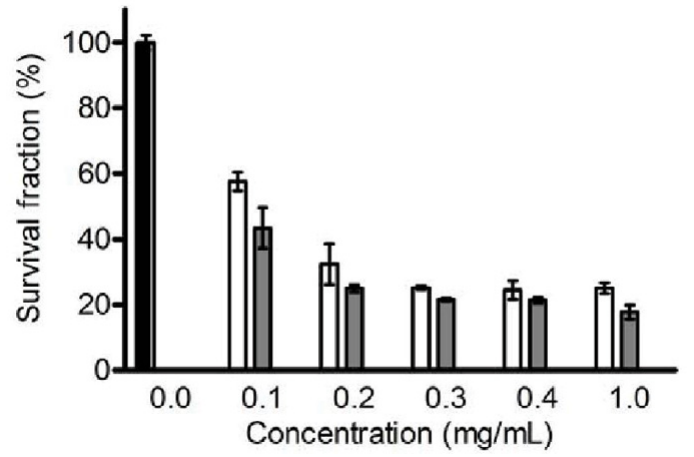

Figure 6: Non-buffered cetyl-myristoleate (white columns) vs. buffered (grey columns) against the human multiple myeloma RPMI.

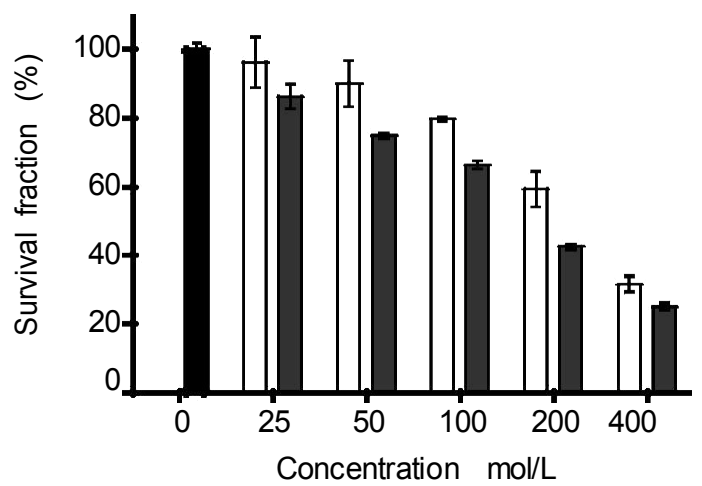

Figure 7: Non-buffered stearinic acid (white columns) vs. buffered (grey columns) against the human chronic myeloid leukemia LAMA-84.

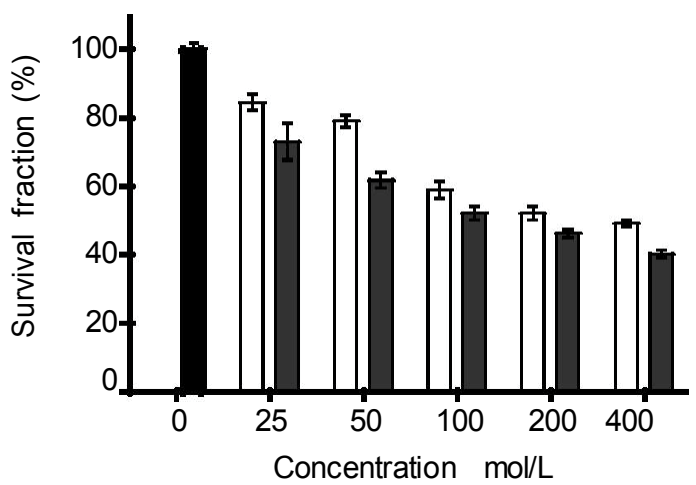

Figure 8: Non-buffered stearinic acid (white columns) vs. buffered (grey columns) against the human bladder carcinoma MGH-U1.

that the cells are up regulating glucose and peroxide metabolism to compensate. Forcing these cells to metabolize fats as their most available energy source has been observed to have a very negative impact on their growth and viability. In a direct human application, a high ketogenic diet would theoretically force these cells to use the very oxidative metabolism they are trying to offset. Hence fat exposure in and of itself (as an energy source) is expected to be anti-neoplastic in nature for several reasons [39].

In these experiments, the acute promyelocyte leukemia HL-60 demonstrated sensitivity to both non-buffered and buffered fats, although the latter proved to be more active as evidenced by the comparison of survival fractions for each concentration. At the highest level evaluated the non-buffered fats lowered the fraction of living cells to approximately $31.7 \%$, while the buffered fats decreased the percentage of viable cells to $21.9 \%$. The $\mathrm{IC}_{50}$ values were $0.41 \mathrm{mg} / \mathrm{ml}$ for the non-buffered fats vs. $0.32 \mathrm{mg} / \mathrm{ml}$ for the buffered ones respectively.

Antiproliferative effects were also established in LAMA-84 cells. As in the preceding cell line, the buffered fats proved to be superior antiproliferative agents as evidenced by the MTT-data. At the highest concentration tested, the non-buffered fats reduced the cellular viability by a calculated $79 \%$, while the buffered fats lowered it by approximately

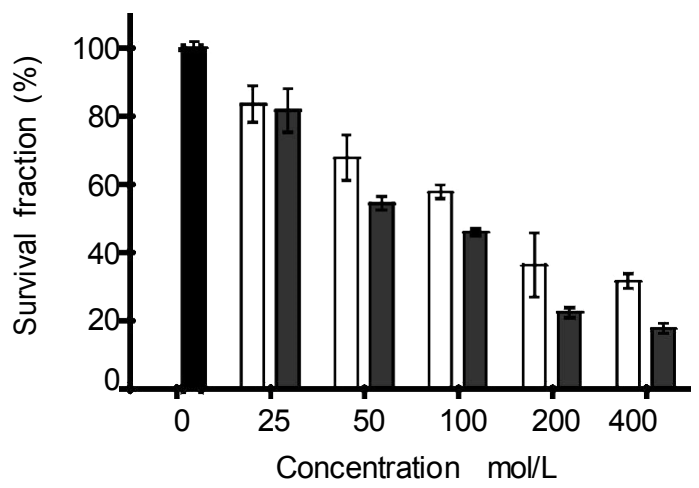

Figure 9: Antiproliferative effects of non-buffered myristic acid (white columns) vs. buffered (grey columns) against the human chronic myeloid leukemia LAMA-84.

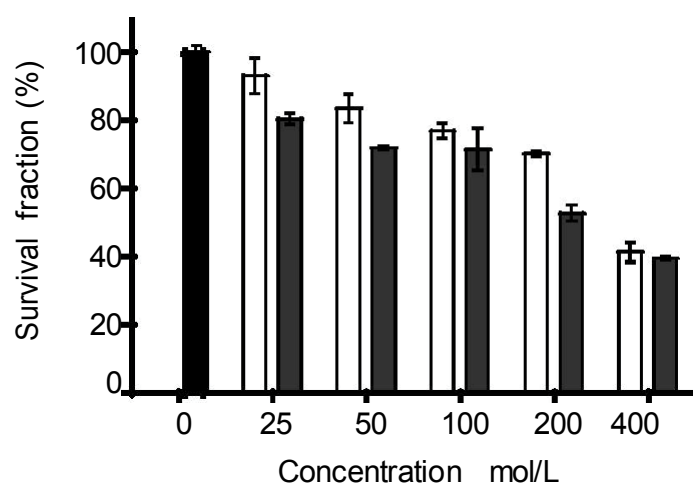

Figure 10: Non-buffered myristic acid (white columns) vs. buffered (grey columns) against the human bladder carcinoma MGH-U1.

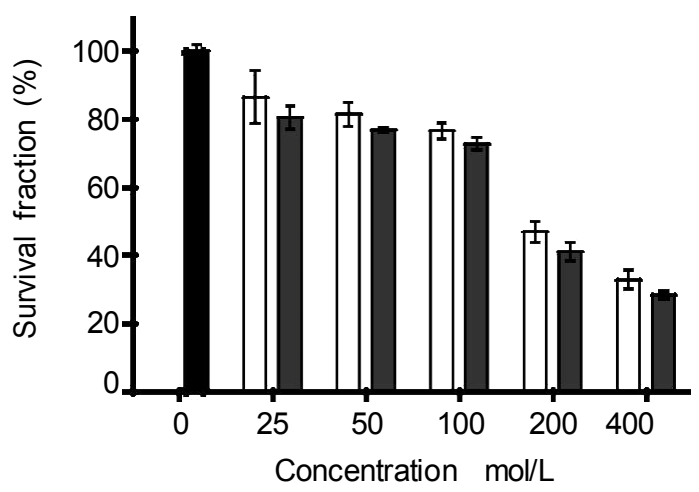

Figure 11: Antiproliferative effects of non-buffered palmitinic acid (white columns) vs. buffered (grey columns) against the human chronic myeloid leukemia LAMA-84. 


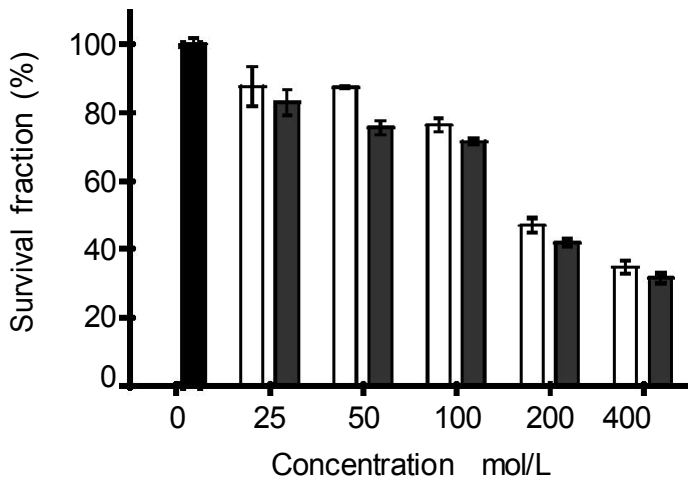

Figure 12: Non-buffered palmitinic acid (white columns) vs. buffered (grey columns) against the human bladder carcinoma MGH-U1.

$84 \%$. The $\mathrm{IC}_{50}$ values obtained were $0.18 \mathrm{mg} / \mathrm{ml}$ for the non-buffered and $0.12 \mathrm{mg} / \mathrm{ml}$ for the buffered.

The evaluation of the antiproliferative effects of tested compounds against the Hodgkin lymphoma derived cell line HD-MY-Z revealed that buffered fats exerted a stronger inhibitory activity. At a concentration of $1 \mathrm{mg} / \mathrm{ml}$ the viable cells were 30.7 after exposure to non-buffered fats and 26.8 after treatment with buffered fats. The calculated $\mathrm{IC}_{50}$ values $-0.27 \mathrm{mg} / \mathrm{ml}$ for non-buffered fats vs. $0.22 \mathrm{mg} /$ $\mathrm{ml}$ for the buffered ones.

\section{Conclusion}

The presented data indicates that throughout the panel of malignant cells the buffered fats exerted a more pronounced antiproliferative effects vs. the non-buffered fats, as evidenced by comparison of survival fractions after treatment with equivalent concentrations. This data also supports the concept that introducing a treatment substance, in an alkaline buffered environment, contributed toward inhibition of neoplastic cell growth and survival. A pH modified strategy warrants further investigation and should be considered when designing an antineoplastic therapy modality.

\section{Acknowledgments}

The author would like to thank senior researcher, Asst. Prof. Georgi Tsvetanov Momekov, MPharm, PhD, and Lab Technician: Mrs. Theodora Atanassova, BSc Department of Pharmacology, Pharmacotherapy and Toxicology Lab of Experimental Chemotherapy and Molecular Pharmacology, 1000 Sofia.

\section{References}

1. Colegio OR, Chu NQ, Szabo AL, Chu T, Rhebergen AM, et al. (2014) Functional polarization of tumour-associated macrophages by tumour-derived lactic acid. Nature 25; 513: 559-563.

2. Pouysségur J, Franchi A, Pagès $\mathrm{G}$ (2001) pHi, aerobic glycolysis and vascular endothelial growth factor in tumour growth. Novartis Found Symp 240:186-198

3. Murphy AM, Lyons CL, Finucane OM, Roche HM (2014) Interactions between differential fatty acids and inflammatory stressors-impact on metabolic health. Prostaglandins Leukot Essent Fatty Acids 3.

4. Das U (2007) A radical approach to cancer. Med Sci Monit 8: 79-92.

5. Madhavi N, Das UN, Prabha PS, Kumar GS, Koratkar R, et al. (1994) Suppression of human T-cell growth in vitro by cis-unsaturated fatty acids: relationship to free radicals and lipid peroxidation. Prostaglandins Leukot Essent Fatty Acids 51: 33-40.

6. Sagar PS, Das UN (1995) Cytotoxic action of cis-unsaturated fatty acids on human cervical carcinoma (HeLa) cells in vitro. Prostaglandins Leukot Essent Fatty Acids 53: 287-299.
7. Madhavi N, Das UN (1994) Effect of $n-6$ and $n-3$ fatty acids on the survival of vincristine sensitive and resistant human cervical carcinoma cells in vitro. Cancer Lett 29; 84: 31-41.

8. Cazzola R, Cassani E, Barichella M, Cestaro B (2013) Impaired fluidity and oxidizability of HDL hydrophobic core and amphipathic surface in dyslipidemic men. Metabolism 62: 986-991

9. Cazzola R, Rondanelli M, Trotti R, Cestaro B (2011) Effects of weight loss on erythrocyte membrane composition and fluidity in overweight and moderately obese women. J Nutr Biochem 22: 388-392.

10. Lu XF, He GQ, Yu HN, Ma Q, Shen SR, et al. (2010) Colorectal cancer cell growth inhibition by linoleic acid is related to fatty acid composition changes. $J$ Zhejiang Univ Sci B 11: 923-930

11. Cestaro B, Cazzola R, Rondanelli M, Ferrari E (2001) Membrane fluidity and obesity: the correct food approach. Minerva Gastroenterol Dietol 47: 181-185.

12. Franklin BS, Bossaller L, De Nardo D, Ratter JM, Stutz A, et al. (2014) The adaptor ASC has extracellular and 'prionoid' activities that propagate inflammation. Nat Immunol 15: 727-737.

13. Turturici G, Tinnirello R, Sconzo G, Geraci F (2014) Extracellular membrane vesicles as a mechanism of cell-to-cell communication: advantages and disadvantages. Am J Physiol Cell Physiol 1; 306: 621-633.

14. Innis SM (2007) Dietary lipids in early development: relevance to obesity immune and inflammatory disorders. Curr Opin Endocrinol Diabetes Obes 14: 359-364.

15. Nakanishi M, Hirayama E, Kim J (2001) Characterization of myogenic cel membrane: II. Dynamic changes in membrane lipids during the differentiation of mouse C2 myoblast cells. Cell Biol Int 25: 971-979.

16. Deliconstantinos G (1987) Physiological aspects of membrane lipid fluidity in malignancy. Anticancer Res 7: 1011-1021.

17. Wickramasinghe NS, Jo H, McDonald JM, Hardy RW (1996) Stearate inhibition of breast cancer cell proliferation. A mechanism involving epidermal growth factor receptor and G-proteins. Am J Pathol 148: 987-995.

18. Simon JA, Fong J, Bernert JT, Jr. (1996) Serum fatty acids and blood pressure. Hypertension, 27: 303-307.

19. Diggle CP (2002) In vitro studies on the relationship between polyunsaturated fatty acids and cancer: tumour or tissue specific effects? Prog Lipid Res 41: 240-253.

20. Ritchie SA, Jayasinghe D, Davies GF, Ahiahonu P, Ma H, et al. (2011) Human serum-derived hydroxy long-chain fatty acids exhibit anti-inflammatory and anti-proliferative activity. J Exp Clin Cancer Res 17; 30: 59.

21. Serhan CN, Clish CB, Brannon J, Colgan SP, Gronert K, et al. (2000) Antimicro inflammatory lipid signals generated from dietary $\mathrm{N}-3$ fatty acids via cyclooxygenase-2 and transcellular processing: a novel mechanism for NSAID and N-3 PUFA therapeutic actions. J Physiol Pharmacol 51: 643-654.

22. Hesslink R Jr., Armstrong D, Nagendran MV, Sreevatsan S, Barathur R (2002) Cetylated fatty acids improve knee function in patients with osteoarthritis. $J$ Rheumatol 29:1708-1712.

23. Choy, EHS, Panayi,GS (2001) Cytokine pathways and joint inflammation in rheumatoid arthritis. NEJM 344: 907-916.

24. Ritchie SA, Tonita J, Alvi R, Lehotay D, Elshoni H, et al. (2013) Low-serum GTA-446 anti-inflammatory fatty acid levels as a new risk factor for colon cancer. Int J Cancer 15; 132: 355-362

25. Evans LM, Cowey SL, Siegal GP, Hardy RW (2009) Stearate preferentially induces apoptosis in human breast cancer cells. Nutr Cancer 61: 746-53.

26. Grossmann ME, Mizuno NK, Schuster T, Cleary MP (2010) Punicic acid is an omega- 5 fatty acid capable of inhibiting breast cancer proliferation. Int $\mathrm{J}$ Oncol 36: 421-426.

27. Simonsen NR, Fernandez-Crehuet Navajas J, Martin-Moreno JM, Strain JJ, Huttunen JK, et al. (1998) Tissue stores of individual monosaturated fatty acids and breast cancer: the EURAMIC study. European community multi center study on antioxidants myocardial infarction and breast cancer. American journal of clinical nutrition 68: 134-141.

28. Shapiro S (1996) The inhibitory action of fatty acids on oral bacteria. Ora Microbiol Immunol 11: 350-355. 
Citation: Golini J, Jones W (2014) Buffered vs. Non-Buffered Aliphatic Fatty Acids and their Anti-Proliferative Effects in Human Tumor Cell Lines. Single Cell Biol 4: 107. doi:10.4172/2168-9431.1000107

Page 6 of 6

29. Galdiero F, Folgore A, Galdiero M, Tufano MA (1990) Effect of modification of HEp 2 cell membrane lipidic phase on susceptibility to infection from herpes simplex virus. Infection 18: 372-375

30. Iguchi K, Okumura N, Usui S, Sajiki H, Hirota K, et al. (2001) Myristoleic acid, a cytotoxic component in the extract from Serenoa repens, induces apoptosis and necrosis in human prostatic LNCaP cells. Prostate 47: 59-65.

31. Estrella V, Chen T, Lloyd M, Wojtkowiak J, Cornnell HH, et al. (2013) Acidity generated by the tumor microenvironment drives local invasion. Cancer Res 1; 73: 1524-1535.

32. Gorbatenko A, Olesen CW, Boedtkjer E, Pedersen SF (2014) Regulation and roles of bicarbonate transporters in cancer. Front Physiol 5: 130.

33. McCarty MF, Whitaker J (2010) Manipulating tumor acidification as a cancer treatment strategy. Altern Med Rev 15: 264-272.

34. Silva AS, Yunes JA, Gillies RJ, Gatenby RA (2009) The potential role of systemic buffers in reducing intratumoral extracellular $\mathrm{pH}$ and acid-mediated invasion. Cancer Res 15; 69: 2677-2684.
35. Robey IF, Baggett BK, Kirkpatrick ND, Roe DJ, Dosescu J, et al. (2009) Bicarbonate increases tumor $\mathrm{pH}$ and inhibits spontaneous metastases. Cancer Res 15; 69: 2260-2268.

36. Fukamachi T, Ikeda S, Saito H, Tagawa M, Kobayashi H (2014) Expression of acidosis-dependent genes in human cancer nests. Mol Clin Oncol 2: 11601166.

37. Fukamachi T, Ikeda S, Saito H, Tagawa M, Kobayashi H (2014) Expression of acidosis-dependent genes in human cancer nests. Mol Clin Oncol 2: 1160 1166.

38. Vaupel $P$, Kallinowski $F$, Okunieff $P$ (1989) Blood flow, oxygen and nutrient supply, and metabolic microenvironment of human tumors. Cancer Res 49: 6449-6465.

39. Allen BG, Bhatia SK, Anderson CM, Eichenberger-Gilmore JM, Sibenaller ZA, et al. (2014) Ketogenic diets as an adjuvant cancer therapy: History and potential mechanism. Redox Biol 7; 2C: 963-970. 